\title{
GEOLOGIC MAP OF THE BEAVER CREEK AREA IN THE GRENVILLE LOWLANDS, ST. LAWRENCE COUNTY, NEW YORK
}

\author{
By C. Ervin Brown
}

\section{GEOLOGIC SETTING}

The Beaver Creek area is a zone of intensely folded metamorphic rocks of the Grenville Complex in the Grenville lowlands northwest of the Adirondacks in New York. The area underwent regional metamorphism to the upper amphibolite facies about 1 b.y. ago. Pegmatite, granite, and gabbro intruded the region essentially syntectonically. Recurrent faulting that was initiated early during tectonism has separated the area into distinct structural domains.

Shallow intrusion by diabase occurred in the Late Proterozoic or Early Cambrian (Brown, 1983) after many kilometers of rock were eroded. The diabase formed dikes that trend northeastward, but are not obviously aligned with the northeast-trending folds, faults, and layering in the host rock. They intrude many rock types of the Grenville Complex. Some dikes are alkalic (Brown, 1975), amygdaloidal, and have chilled borders. If they reached the surface, the resultant effusive rocks have not been preserved. The dikes are truncated at the unconformity beneath the overlying Upper Cambrian Potsdam Sandstone.

The Potsdam Sandstone is essentially flat lying and occurs mainly as thin outliers of Paleozoic rocks that now are northwest and west of the Beaver Creek area. Many small sandstone bodies fill low areas and cavities in the marbles beneath the unconformity. The sand probably was derived from the Potsdam Sandstone, but might also represent siliceous sediments that were deposited and stripped away prior to deposition of the Potsdam. Some Potsdam outliers have been faulted and warped and it is not known whether this deformation results from slumping in areas of dissolved carbonate rock or from a late tectonic event (Brown, 1983, p. 4). There is evidence for both processes, but neither has affected the major tectonic features of the rocks of Proterozoic age.

\section{STRUCTURAL GEOLOGY}

The geologic map shows the interpreted folds and faults in the area. Folding is multiple and three distinct phases are identified throughout the area. Although the major structural picture can be described on the basis of three principal folding events, in many outcrops, more than three phases can be observed. Except for the first folding phase $\left(F_{1}\right)$ folds in the Hyde School domical body, $\mathrm{F}_{1}$ fold axes trend northeastward, are overturned to the southeast, and are essentially isoclinal. The North Gouverneur nappe is a major $F_{1}$ recumbent antiform that closes southeastward. Foliation in gneissic rocks is essentially parallel to the axial surfaces of $F_{1}$ folds. The second folding phase $\left(F_{2}\right)$ produced generally upright, open folds whose axes trend to the north-northeast. Phase- 1 folds are refolded to various degrees by $F_{2}$ folds. Third-phase folds $\left(\mathrm{F}_{3}\right)$ in all cases trend northwestward and consist of gentle warps that are continuous, in most cases for about a mile. In steeply dipping rocks, $F_{3}$ folds are identified by reversal of the lineation plunge of the earlier folds. Gently dipping units also show reversals in the dip of layering as a result of $\mathrm{F}_{3}$ folding.

Lineations shown on the map represent minor fold axes, mullions, rods, or aligned minerals. Mullions, minor fold axes, and rods can be seen in gneisses and schists. Carbonate and calc-silicate rocks show mostly minor fold axes. Foliated granites and amphibolitic rocks locally display mineral lineations. Most lineation is parallel to $F_{1}$ fold axes, but in some places it results from $F_{2}$ folding.

Major ductile faulting began tectonically early and is mainly of two types. The most common faults are steeply dipping, curvilinear and had early strike-slip movement. Thrust faults in the lower limb and detachment zone of the North Gouverneur nappe are the second type. A few minor vertical dip-slip faults are also shown. These are young and not related to the principal faults.

The early faulting was accompanied by the intrusion of pegmatite and granitic bodies that were subsequently mylonitized. The early thrust faults were folded during the $F_{2}$ phase. Vertical regional faults also show evidence of much later recurrent movement because brecciated rock and a vein system of probable Paleozoic age can be related to such movement (Brown, 1983, p. 9-10). The minor, steeply dipping faults do not affect the regional geology although some areas of Potsdam Sandstone locally have fault boundaries.

The most obvious aspect of the structural grain in the Beaver Creek area is a division into northeast-trending structural domains. These domains are bounded by the regionally significant curvilinear strike-slip faults. The faults, which extend beyond the map area, can be traced as far as 30 miles and project beneath the Paleozoic cover rocks to the northeast and southwest. Similar faults northwest and southeast of the Beaver Creek area have also been mapped (see fig. 1) (Brown and Engel, 1956; Bannerman, 1972; Guzowski, 1979; Foose, 1980).

The fold pattern of each fault-bounded domain is distinct and the stratigraphic sequences of each can be distinguished from one another. Phase- 1 fold trends commonly vary from domain to domain, and $F_{3}$ folds are confined within the domains. The Beaver Creek area is divided into five major and one subsidiary fault-bounded structural domains that will be individually described and are labeled on the map.

The Beaver Creek fault lineament divides the area nearly in half. The stratigraphic sequences and structural styles on either side of the fault are distinctly different. Because of these differences, and to avoid confusion, the structural domains southeast of the lineament are discussed first, followed by those to the northwest.

Domain A, the North Gouverneur nappe.-The North Gouverneur nappe is a large $F_{1}$ antiform that forms a spindle-shaped map zone extending from the northeast to the southwest extremities of the map area. At either narrow end, the rocks are steeply dipping and overturned to the southeast. In the central wide part, the antiform is recumbent. In this central recumbent zone, the stratigraphic sequence of the upper limb is essentially intact and the trace of the axis, although only approximately located in most places, is precisely located where the closure along Maple Ridge Road $\left(22,700\right.$ N. 65,500 E. $\left.{ }^{1}\right)$ is shown by the "dividing gneiss" unit (dg).

The stratigraphic sequence in the lower limb of the antiform, in contrast, is disrupted by an intranappe thrust fault along which several units are either cut out or severely thinned. The antiform is bounded along the southeast side by a thrust fault upon which the fold overrode subjacent rocks. This detachment fault at most places follows the structurally lower contact of a competent unit of amphibolitic paragneiss (pba). The intranappe fault at places bounds this unit near its upper contact. Near the south edge of the map the paragneiss is either locally cut out by faulting or pulled apart by stretching $(13,500 \mathrm{~N}$., $57,500 \mathrm{E}$.). Here, the intranappe fault has cut through to the nappe sole fault in the gap between outcrop belts of pba.

In the east-central part of the map $(22,000 \mathrm{~N}$., $66,500 \mathrm{E}$.), the detachment fault is folded by a large $\mathrm{F}_{2}$ fold. Here, the nappe includes a structurally lower, but stratigraphically higher, sequence of hornblendic gneisses (uag).

Along the Cream of the Valley Road, both thrust faults are folded by two $F_{2}$ folds $(16,000 \mathrm{~N}$., $61,000 \mathrm{E}$.) that can be traced northward into the

\footnotetext{
${ }^{1}$ Here and throughout this text, the locations of key features can be found using the Universal Transverse Mercator metric coordinates, zone 18. All northerly measurements are plus $4,900,000$ meters and easterly measurements are plus 400,000 meters
} 
upper limb of the recumbent antiform. The upper normal limb of the recumbent antiform is locally rippled by open $\mathrm{F}_{2}$ folds that trend about $\mathrm{N}$. $20^{\circ} \mathrm{E}$. The $\mathrm{F}_{1}$ fold axes trend N. $30^{\circ}-40^{\circ} \mathrm{E}$; , therefore, minor $\mathrm{F}_{1}$ folds related to the recumbent antiform can be distinguished from minor $F_{2}$ folds mainly because they are overturned to the southeast or are recumbent.

Phase- 3 folds are recognized by the reversal of the plunge of earlier lineations. In areas of low dip, broad $\mathrm{F}_{3}$ warps can be mapped. The most notable of these is the broad downwarp with a northwest-trending axis that is $305 \mathrm{~m}$ south of Osborn Lake.

Numerous granitic sheets, the main mass of which is near Huckleberry Mountain, have intruded the nappe at low angles to the layering. Intrusion must have occurred early because the sheets are affected by $F_{1}$ folding and a granitic unit (ma) was intruded and mylonitized along the detachment fault.

Domain $A^{\prime}$, isoclinal $F_{1}$ folds along east bank of Beaver Creek. -Along the east bank of Beaver Creek is a belt of isoclinal $F_{1}$ folds with steeply northwestward-dipping axial surfaces. This area appears to be the steeply dipping root zone of the North Gouverneur nappe of domain $A$ (sections $\left.A-A^{\prime}, B-B^{\prime}\right)$. The narrow zone of tight folds is partly bounded on the southeast by a steeply dipping fault with minor offset. The fault dies out to the northeast, but the zone of tight, southwest-plunging folds continues northeastward in the narrow point of land bounded by the swamps of Beaver Creek and South Fork of Beaver Creek. To the northeast, across the swamp from the narrow point of land, are similar rocks that are closely interlayered with metagabbro, granite, and amphibolitic feldspathic rocks (afg). Lineations here plunge to the south and stratigraphic arrangement suggests a complex synform. I believe this is the refolded continuation of the tight isoclinal $F_{1}$ fold zone of structural domain $A^{\prime}$, refolded by a major $F_{2}$ synform and antiform that are bounded by a fault on the southeast side. The arrangement of the talc-tremolite schist (ttq) occurrences relative to marble (qm) in the swamp north of Osborn Lake supports a refolding hypothesis. This structure is similar in some respects to the Z-fold at the northeast end of the Balmat-Edwards synform, described by Brown and Engel (1956).

Southwest of Huckleberry Mountain, the isoclinal $F_{1}$ folds of domain $\mathrm{A}^{\prime}$ become indistinct and the metasedimentary units pda, csq, and qmt are interleaved or infolded with amphibolitized feldspathic rock (afg), granite $(\mathrm{hhg})$, and metagabbro $(\mathrm{mg})$. The distribution of rocks here is similar to that in the extreme northeast end of domain $A^{\prime}$. These rocks southwest of Huckleberry Mountain appear to be thrust slightly southeastward and a thin zone of mylonitized granite (ma) in the midst of the interleaved rocks suggests the possibility of a healed thrust fault similar to the detachment zone of the North Gouverneur nappe.

Domain $B$, rocks overridden by nappe.-The southeastern fringe of the map area includes rocks that are part of a zone overridden by the North Gouverneur nappe. The area along the small oxbow of the Oswegatchie River in the vicinity of Little Bow Road $(15,000$ N., 60,500 E.) has excellent examples of sinuous north- or northwest-trending axial traces of $F_{1}$ folds refolded by northeast-trending $\mathrm{F}_{2}$ folds. Rocks involved correlate with those in the structurally overlying nappe, but the individual folds are not reflected upward into the nappe. Near here, however, the nappe is also sharply refolded by $\mathrm{F}_{2}$ folds. Bannerman (1972) shows similar refolding of the same units in the projected northeast extension of this structural zone between the villages of Richville and DeKalb. This zone also extends southeastward beyond this map and is bounded on the southeast by the Oswegatchie fault zone. The Oswegatchie fault is followed by the Oswegatchie River from Little Bow to Richville and continues northeast of Richville close to U.S. Route 11 (Bannerman, 1972). Late recurrent movement along this fault zone produced widespread brecciation in the tourmaline-rich unit (qmt).

Domain C, zone between Beaver Creek and Hickory-Mud Lakes and Pleasant Lake faults. - On the northwest side of Beaver Creek is a long tapering zone bounded by the Beaver Creek fault and the Hickory-Mud Lakes and Pleasant Lake fault system. This structural zone trends northeastward diagonally across the map for $19 \mathrm{~km}$ and widens from less than $0.8 \mathrm{~km}$ wide at the northeast end to $4 \mathrm{~km}$ wide at the southwest end. The bounding faults possibly join northeast of the map area.

The stratigraphic sequence in structural domain $\mathrm{C}$ does not correlate well with that of the North Gouverneur nappe, and I believe it to be a stratigraphically lower part of the metasedimentary sequence (see geologic map). Rocks here are mostly rusty, silicated, carbonate-rich gneisses (rsm) including much quartzite and metapelitic rock along the western part of the zone. A belt of coarse-grained calcitic marble $(\mathrm{cm})$ is centrally located, and possibly correlates with the lowest marble $(\mathrm{mm})$ in the North Gouverneur nappe.

This structural domain is characterized by extreme attenuation and ductile deformation of the carbonate rocks. Layers of more competent rocks such as quartzite are broken into blocks that are widely separated and aligned in trails at both map and outcrop scale. The rocks display excellent flow layering that is isoclinally folded. These $F_{2}$ folds have length to width ratios of at least 20 to 1 , are upright, and have limbs that dip steeply to the northwest or southeast. Phase-1 folds are mostly destroyed or unidentifiable. The bifurcation of the calcitic marble $(\mathrm{cm})$ belt $(24,500 \mathrm{~N}$., 61,500 E.), is probably a result of the refolding of an $F_{1}$ fold. Other possible examples of $F_{1}$ folds are in the wide, southwest end of the domain where flowage and attenuation are not as extreme and competent units are more intact. Phase- 3 fold axes are short and trend northwest as shown by reversals of the plunges of $F_{2}$ fold axes. These are simple warps in contrast to the complex $F_{1}$ and $F_{2}$ folds. I believe the extreme disruption, attenuation, flowage, and thin, tapering shape of domain $\mathrm{C}$ was caused by torsional compression of a slab of incompetent rocks caught between the two converging bounding faults.

The aligned bodies of porphyroblastic granitic gneiss (bcg) along Beaver Creek in this zone are all spindle-shaped. Some show strong shearing in the form of elliptical augens. I believe these bodies were intruded early along the proto-Beaver Creek fault and subsequently were stretched and possibly formed into boudins by the same processes that attenuated the metasedimentary rocks in domain $\mathrm{C}$. Granites that occur along either side of the Beaver Creek lineament are significantly different, suggesting considerable lateral displacement along the fault following intrusion of the granitic rocks.

Domain D, Hickory-Mud Lakes fault slice. - The domain between the Pleasant Lake fault and the Hickory-Mud Lakes fault, only $9 \mathrm{~km}$ long and 0.8 to $1.6 \mathrm{~km}$ wide, contains folds that differ distinctly in both trend and style from those in adjacent zones. The fault and fold arrangement on the map suggests that the Hickory-Mud Lakes fault is a splay of the Pleasant Lake fault and possibly rejoins it near Mud Lake, leaving a slice of rocks between them. These rocks are rotated and the fold axes now are nearly perpendicular to the bounding faults. The narrow zone is characterized by northwest- to west-trending $F_{1}$ folds that are either recumbent or overturned to the south.

In the southern part of the slice, the $F_{1}$ folds are refolded by northeast-trending $\mathrm{F}_{2}$ folds. Phase- 2 folds plunge eastward at a large angle to the $\mathrm{F}_{2}$ folds in the adjacent domain to the east. In the wider part of this slice, near and southeast of Mud Lake, only one major set of folds is obvious. These are overturned to the south, extend transversely across the domain and plunge gently eastward. Their position suggests $90^{\circ}$-clockwise rotation of the folds, during faulting, by right-lateral movement of the Pleasant Lake-Hickory-Mud Lakes fault system. In this same place, a north-dipping thrust fault best explains the discordant relationship between attitudes in the rusty biotite-quartz-plagioclase rock (bsq) and layering in structurally underlying rusty carbonate gneiss $(\mathrm{rsm})(25,000 \mathrm{~N}$., 60,500 E.).

Part of domain D is shown in more detail on the map of the Birch Creek area (Brown, 1988). The unit shown here as bsq includes three different rock types that are shown separately on that detailed map. A unit of rusty biotite-plagioclase schist containing interleaved carbonate- and scapolite-rich layers (unit bpsc) only occurs in this fault-bounded slice. A possible explanation is that strike-slip faulting has moved different facies into juxtaposition.

Domain E, Hyde School and Hickory Lake gneiss domes. - West of the Pleasant Lake fault zone are two domical bodies of foliated granitoid rocks surrounded by a wide, flatbottomed valley that includes Hickory Lake, the Birch Creek flood plain, and the swamp along Fish Creek. These domical bodies and twelve others in the Grenville lowlands (see fig. 1) were first described as phacoliths by Buddington (1929). Later workers have had various theories for their origin. Carl and Van Diver (1975) determined that the chemistry and distribution of the rocks most closely matches ash-flow tuffs of rhyolitic to dacitic compositions. A detailed field study (Brown, 1988) reveals a mappable stratigraphic sequence in the domical bodies that includes foliated granitoid rocks having granitic, trondhjemitic, and dioritic compositions.

The most obvious structures in this zone are the two northeasttrending elongate antiforms in gneiss that are warped into domes and saddles by broad open folds that trend northwestward. Detailed mapping (Brown, 1988) reveals an earlier set of folds that are particularly well shown in the southernmost dome of the Hyde School body, where at least three separate fold phases seen in the other structural domains are also present. An early $F_{1}$ fold, identified in the south dome of the Hyde School antiform, is shown by the large crescent-shaped area of alaskitic granitoid. Enveloped within the horns of this crescent-shaped fold area, and on either flank of the inner part of the south dome, are two southward-closing $F_{1}$ fold apices, each with a plunge nearly parallel to the dip of the fold plane. The two apices actually are part of the same fold repeated on opposite sides of the south dome by $\mathrm{F}_{2}$ folding. A zone in the north dome, near the intersection of Cooper and Hyde Roads, has many minor recumbent folds that are shown by the folded amphibolite layers (Buddington, 1934, fig. 44; Engel and Engel, 1963, figs. 1 and 2). I believe these folds are in the vicinity of an axial surface of the major $\mathrm{F}_{1}$ "isoclinal" fold domed by later folding (see fig. 
2). The presence of this earlier fold was also postulated by Foose and Carl (1977, p. 80).

A feature of secondary importance to my structural interpretation of the Hyde School body is recognition of a structural discontinuity in the south dome at the inner contact of the crescentic area of alaskite. The outer limb and fold surface of the $F_{1}$ fold that occupies the central part of the south dome is truncated by this contact. Also, the distribution of the two alaskite types ( $\mathrm{aa}$ and al) is not symmetrical across the crescentic $\mathrm{F}_{1}$ fold. I believe this contact is a folded ductile fault zone, along which units are cut out or attenuated to the point of disappearance.

The sequential structural development of the Hyde School domical body is shown in figure 2 and is discussed in detail elsewhere (Brown, 1988). The Hickory Lake antiform appears to be a simple, doubly plunging antiform or sheath fold produced by the last two phases of folding. Except for minor folds, early isoclinal folds have not been recognized here and lineations are mainly minor $F_{1}$ fold axes that show a reversal of plunge produced by the $\mathrm{F}_{2}$ antiform.

Folds in the metasediments overlying the domes are disharmonious with those in the underlying gneiss. This suggests different tectonic histories, because of either a decollement or an unconformity between gneiss and overlying metasediments, or simply a different tectonic style because of ductility contrast between a thick, competent, underlying gneiss sequence and the overlying incompetent, heterogeneous, carbonate-bearing rocks.

\section{DIKE INTRUSION}

Structural control for the emplacement of the vertical diabase dikes in the Beaver Creek area is enigmatic. The dikes are part of a swarm that are more numerous to the southwest near the Thousand Islands and to the west in Ontario. Dikes are emplaced in simple dilation fractures that do not change in width at changes in trend, suggesting tension operating at an angle less than $90^{\circ}$ to their trend. In the Beaver Creek area, the overall trend of the dikes is N. $55^{\circ}$ to N. $60^{\circ} \mathrm{E}$. This trend is 20 to 30 degrees farther east than is the average trend of layering and faults in the region. The style of the course of the dikes, as shown by the principal dike in the area, is zig-zagged, having long north-northeast segments and shorter northeast segments. Less prominent parallel dikes also show this pattern of short clockwise shifts in dike trend.

Local geologic features apparently had little control over the dike trends. At three places in the area, dikes cross major faults at an angle of about 30 degrees, and have no lateral offset. Only in domain $\mathrm{C}$, west of Beaver Creek, does the principal dike seem to be aligned for short distances with lithologic boundaries that are steeply dipping in this domain. However, east of the Beaver Creek lineament where the dip of contacts is more gentle, the vertical dike cuts through a great variety of rocks with no apparent influence by rock type or contacts. Apparently the emplacement of the dikes is due to forces more regional in scope or more deeply seated than can be interpreted from the geologic details of the Beaver Creek area.

\section{CONCLUSIONS}

The Middle Proterozoic metamorphic rocks of the Grenville Complex in the Beaver Creek area were metamorphosed and tectonically deformed about 1 b.y. ago. Pegmatite, granite, and gabbro were intruded essentially syntectonically, largely in or near early fault zones. After many kilometers of rock were eroded, diabase was intruded as dikes in a near-surface environment probably during the Late Proterozoic. Potsdam Sandstone of Late Cambrian age was laid down on an erosional surface of low relief and an undetermined thickness of sedimentary rocks of Early Paleozoic age was deposited above the sandstone. Subsequent uplift and arching along a northwest-trending zone, the Frontenac axis, allowed the sedimentary cover to be stripped and the rocks of Proterozoic age to be re-exposed.

At least three phases of folding affected the Middle Proterozoic rocks of the Beaver Creek area. Phase-1 folds are generally isoclinal and overturned and in some areas are destroyed or unidentified because of subsequent tectonic deformation. Most minor folds and lineations reflect $F_{1}$ folding. Phase- 2 folds generally trend to the northeast and are upright and open. Phase- 3 folds trend to the northwest and southeast, are not extensive, and their axes are identified by the reversal of plunge of lineations formed during $F_{1}$ or $F_{2}$ folding.

Recurrent, probably mainly strike-slip faulting, was initiated early during tectonism and caused the entire area to be broken into structural zones or domains that have been shuffled laterally to various degrees into their present positions. Early deformation along the faults was ductile, but much later movement had associated brittle deformation. Fold style and orientation are distinctive between domains, and $\mathrm{F}_{2}$ folding in some fault-bounded domains appears to be related to strain developed by the relative strike-slip movements. Stratigraphy of the various domains also has distinct differences, thus suggesting that movement has placed different facies or parts of the stratigraphic column in juxtaposition. The early tectonic events occurred deep in the crust perhaps during a continentcontinent collision (McLelland and Isachsen, 1980). Lateral compensation in the form of transcurrent faulting can be one of the characteristics of such tectonic situations (Dewey and Burke, 1973, p. 691), and thus the northeast-trending faults here may be of that origin.

The emplacement of the northeast-trending diabase dikes does not appear to be related to structures within the Beaver Creek area because the dikes cut across faults, folds, and many rock types with no apparent influence on their trends. Their alkalic composition and emplacement in tensional fractures suggest response to a rifting event in Late Proterozoic or Early Cambrian time (Brown, 1983, p. 9).

Veins composed mainly of calcite, and including sphalerite, galena, and fluorite are in west- or northwest-trending minor faults that I believe are conjugate to recurrent, right-lateral adjustments along the major faults during Paleozoic time (Brown, 1983, p. 9).

\section{REFERENCES CITED}

Bannerman, H.M., 1972, Geologic map of the Richville-Bigelow area, St. Lawrence County, New York: U.S. Geological Survey Miscellaneous Investigations Series, Map I-664, scale 1:18,000.

Books, K.G., 1983, Paleomagnetic study of diabasic dikes and miscellaneous granitic gneisses in St. Lawrence and Jefferson Counties, New York (with foreword and footnotes by C.E. Brown): U.S. Geological Survey Open-file Report 83-226, $21 \mathrm{p}$.

Brown, C.E., 1969, New talc deposit in St. Lawrence County, New York: U.S. Geological Survey Bulletin 1272-D, 13 p.

1970, A sphalerite vein and associated geochemical anomalies in St. Lawrence County, New York: U.S. Geological Survey Professional Paper 700-D, p. D162-D168.

1975, Problematical age of an alkaline analcite-bearing olivine diabase dike in St. Lawrence County, New York [abs.]: Geological Society of America Abstracts with Programs, v. 7, no. 1, p. 31.

1978, Reconnaissance investigation of high-calcium marble in the Grenville Series in St. Lawrence County, New York: U.S. Geological Survey Circular 774, $10 \mathrm{p}$.

1980a, Reconnaissance investigation of high-calcium marble in the Beaver Creek drainage basin of St. Lawrence County, New York, in Proceedings of the Fourteenth Annual Forum on the Geology of Industrial Minerals: New York State Museum Bulletin 436, p. 97-105.

(compiler) 1980b, Chemical analyses of Precambrian rocks from St. Lawrence County, New York, by the U.S. Geological Survey from 1963 through 1972: U.S. Geological Survey Open-file Report $80-664,58 \mathrm{p}$.

1983, Mineralization, mining, and mineral resources in the Beaver Creek area of the Grenville lowlands in St. Lawrence County, New York: U.S. Geological Survey Professional Paper 1279, 21 p.

1988, Geologic map of the Birch Creek area, St. Lawrence County, New York: U.S. Geological Survey Miscellaneous Investigations Series, Map I-1645, scale 1:12,000.

Brown, C.E., and Ayuso, R.A., 1985, Significance of tourmaline-rich rocks in the Grenville Complex of St. Lawrence County, New York: U.S. Geological Survey Bulletin 1626-C, 33 p.

Brown, J.S., and Engel, A.E.J., 1956, Revision of Grenville stratigraphy and structure in the Balmat-Edwards district, northwest Adirondacks, New York: Geological Society of America Bulletin, v. 67, no. 12, p. 1599-1622.

Buddington, A.F., 1929, Granite phacoliths and their contact zones in the north-western Adirondacks: New York State Museum Bulletin 281, p. 51-107.

-1934, Geology and mineral resources of the Hammond, Antwerp, and Lowville quadrangles: New York State Museum Bulletin 296, $251 \mathrm{p}$.

1939, Adirondack igneous rocks and their metamorphism: Geological Society of America Memoir 7, $354 \mathrm{p}$.

Carl, J.D., 1978, Ribbed moraine-drumlin transition belt, St. Lawrence Valley, New York: Geology, v. 6, p. 562-566.

Carl, J.D., and Van Diver, B.B., 1975, Precambrian Grenville alaskite bodies as ash-flow tuffs, northwest Adirondacks, New York: Geological Society of America Bulletin, v. 86, p. 1691-1707.

Dewey, J.F., and Burke, K.C., 1973, Tibetan, Variscan, and Precambrian basement reactivation-Products of continental collision: Journal of Geology, v. 81, p. 683-692. 
Dietrich, R.V., 1953, Conical and cylindrical structures in the Potsdam Sandstone, Redwood, New York: New York State Science and Museum Service Circular 34, 19 p.

1954, Fish Creek phacolith, northwestern New York: American Journal of Science, v. 252, no. 9, p. 513-531.

1963, Banded gneisses of eight localities: Norsk Geologisk Tidsskrift, v. 43, no. 1, p. 89-119.

Engel, A.E.J., and Engel, C.G., 1953, Origin and metamorphism of the major paragneiss, part 2 of Grenville series in the northwest Adirondack mountains, New York: Geological Society of America Bulletin, v. 64 , no. 9, p. 1049-1097.

1963, Metasomatic origin of large parts of the Adirondack phacoliths: Geological Society of America Bulletin, v. 74, p. 349-352.

Foose, M.P., 1980, Maps showing geology and structure of the Bigelow area, Northwest Adirondacks, New York: U.S. Geological Survey Miscellaneous Field Studies Map MF-1187.

Foose, M.P., and Brown, C.E., 1976, A preliminary synthesis of structural, stratigraphic, and magnetic data from part of the northwest Adirondacks, New York: U.S. Geological Survey Open-file Report 76-281, $21 \mathrm{p}$.

Foose, M.P., and Carl, J.D., 1977, Setting of alaskite bodies in the northwestern Adirondacks, New York: Geology, v. 5, p. 77-80.

Guzowski, R.V., 1979, Stratigraphy, structure, and petrology of the Precambrian rocks in the Black Lake region, northwest Adirondacks,
New York: Syracuse, N.Y., Syracuse University, unpublished Ph.D. dissertation, $184 \mathrm{p}$.

Isachsen, Y.W., and Landing, Ed, 1983, First Proterozoic stromatolites from the Adirondack massif-Stratigraphic, structural, and depositional implications [abs.]: Geological Society of America Abstracts with Programs, v. 15 , no. 6 , p. 601 .

Lewis, J.R., 1969, Structure and stratigraphy of the Rossie complex, northwest Adirondacks, New York: Syracuse, N.Y., Syracuse University, unpublished $\mathrm{Ph} . \mathrm{D}$. dissertation, $141 \mathrm{p}$.

McLelland, James, and Isachsen, Yngvar, 1980, Structural synthesis of the southern and central Adirondacks-A model for the Adirondacks as a whole and plate-tectonics interpretations: Geological Society of America Bulletin, v. 91, part II, p. 208-292.

Nockolds, S.R., 1954, Average chemical compositions of some igneous rocks: Geological Society of America Bulletin, v. 65, p. 1007-1032.

Selleck, B.W., 1975, Paleoenvironments and petrography of the Potsdam Sandstone, Theresa Formation and Ogdensburg Dolomite of the southwestern St. Lawrence Valley, New York: Rochester, N.Y., University of Rochester, unpublished Ph.D. dissertation.

Wiener, R.W., McLelland, J.M., Isachsen, Y.W., and Hall, L.M., 1984, Stratigraphy and structural geology of the Adirondack Mountains, New York-Review and synthesis: Geological Society of America Special Paper 194, p. 1-55.

TABLE 1.- Results of auger drilling in Beaver Creek area. ${ }^{1}$

\begin{tabular}{|c|c|c|c|c|}
\hline \multicolumn{5}{|c|}{ UTM COORDINATES ${ }^{2}$} \\
\hline Test hole no. & Northing & Easting & (meters) & \\
\hline 1 & 18,620 & 63,620 & $\begin{array}{r}0-10.7 \\
19.7-11.9 \\
11.9-12.2\end{array}$ & $\begin{array}{l}\text { Sticky, gray clay; isolates boulders at } 5 \text { and } 10 \mathrm{~m} \\
\text { Sand and gray clay } \\
\text { Bedrock; biotite-quartz-muscovite gneiss (qmt); well- } \\
\quad \text { layered; contains tourmaline }\end{array}$ \\
\hline 2 & 18,670 & 63,600 & $\begin{array}{r}0-1.5 \\
1.5-7.6 \\
7.6-13.7 \\
13.7-18.3 \\
18.3-18.6\end{array}$ & $\begin{array}{l}\text { Road fill } \\
\text { Black, organic muck, clay, and wood } \\
\text { Gray to bluish-gray, sticky clay } \\
\text { Sand and gravel (artesian water flow) } \\
\text { Bedrock; biotite-oligoclase-quartz gneiss (qmt) }\end{array}$ \\
\hline 3 & 18,710 & 63,610 & $\begin{array}{r}0-0.6 \\
0.6-8.8 \\
8.8-9.1\end{array}$ & $\begin{array}{l}\text { Soil } \\
\text { Blue-gray, sticky clay with sand and gravel at bottom } \\
\text { Biotite-plagioclase-quartz gneiss (qmt) bedrock at } 8.8 \\
\quad \mathrm{~m}\end{array}$ \\
\hline 4 & 22,210 & 65,200 & $\begin{array}{r}0-1.2 \\
1.2-13.8 \\
13.8-16.8 \\
16.8-17.1\end{array}$ & $\begin{array}{l}\text { Road fill } \\
\text { Blue-gray, varved, sticky clay } \\
\text { Sand, clay with boulders; (artesian water flow at } 17 \\
\text { meters) } \\
\text { Bedrock (qm), buff to cream dolomite with diopside } \\
\text { mainly altered to green serpentine }\end{array}$ \\
\hline 5 & 25,750 & 66,950 & $\begin{array}{r}0-3.7 \\
3.7-14.9 \\
14.9-22.0\end{array}$ & $\begin{array}{l}\text { Silty, light-brown clay (loess?) } \\
\text { Gray-blue, varved, sticky clay } \\
\text { Sand, clay, and boulders; artesian flow, water has } \\
\text { bubbles of odorless gas }\left(\mathrm{CO}_{2}\right) \text {; bedrock not } \\
\text { reached }\end{array}$ \\
\hline
\end{tabular}

${ }^{1}$ Drilling done in 1971 by John Windolph and George Hayes of the U.S. Geological Survey using truck-mounted drill equipped for diamond drilling through the hollow auger drill stem.

${ }^{2}$ All northings are plus $4,900,000 \mathrm{~m}$ and all eastings are plus $400,000 \mathrm{~m}$. 
TABLE 2.-Chemical analysis of gabbroic anorthosite. 1, Cumulate textured gabbroic anorthosite from knob south of State Route 58 at Beaver Creek (analysis by D. Kobilis, U.S. Geological Survey); 2, Average norite of Nockolds (1954, p. 1020).

\begin{tabular}{|lcc|}
\hline & 1 & 2 \\
$\mathrm{SiO}_{2}$ & (in percent) & (in percent) \\
$\mathrm{Al}_{2} \mathrm{O}_{3}$ & 51.7 & 50.28 \\
$\mathrm{Fe}_{2} \mathrm{O}_{3}$ & 18.7 & 17.6 \\
$\mathrm{FeO}$ & 1.9 & 1.30 \\
$\mathrm{MgO}$ & 3.9 & 7.46 \\
$\mathrm{CaO}$ & 6.5 & 9.27 \\
$\mathrm{Na} \mathrm{O}_{2} \mathrm{O}$ & 10.7 & 9.72 \\
$\mathrm{~K}_{2} \mathrm{O}$ & 3.1 & 1.96 \\
$\mathrm{H}_{2} \mathrm{O}+$ & 1.5 & 0.63 \\
$\mathrm{H}_{2} \mathrm{O}-$ & 0.88 & 0.47 \\
$\mathrm{TiO}_{2}$ & 0.12 & --- \\
$\mathrm{P}_{2} \mathrm{O}_{5}$ & 0.44 & 0.89 \\
$\mathrm{MnO}$ & 0.13 & 0.21 \\
$\mathrm{CO}_{2}$ & 0.17 & 0.14 \\
& 0.29 & --- \\
& & 100 \\
\hline
\end{tabular}




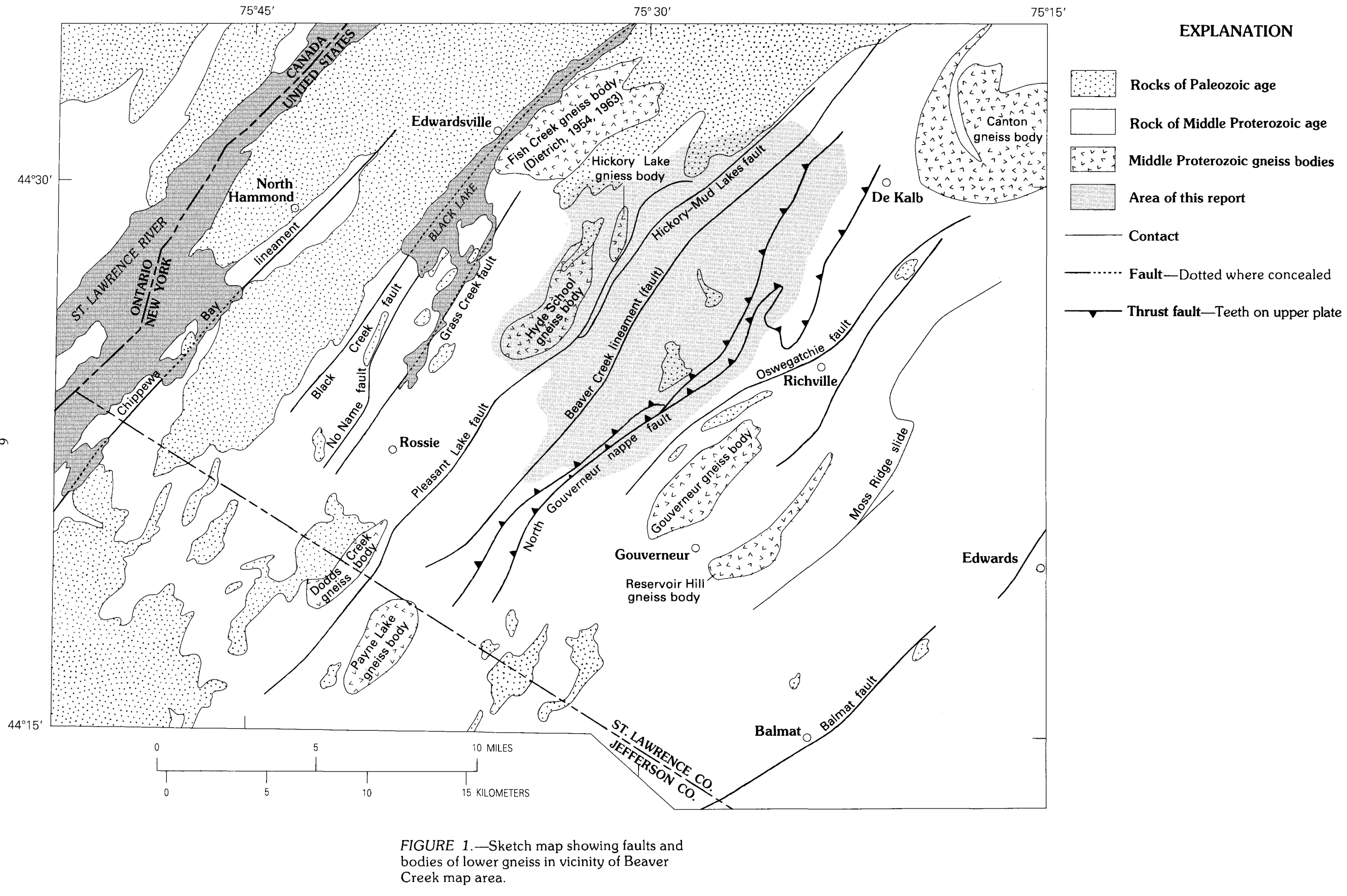




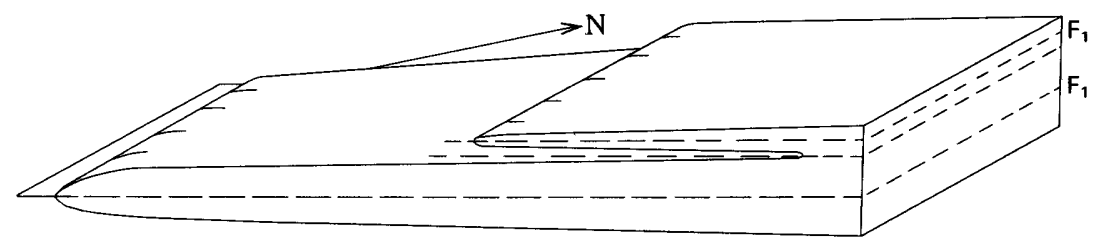

$F_{1}$ recumbent
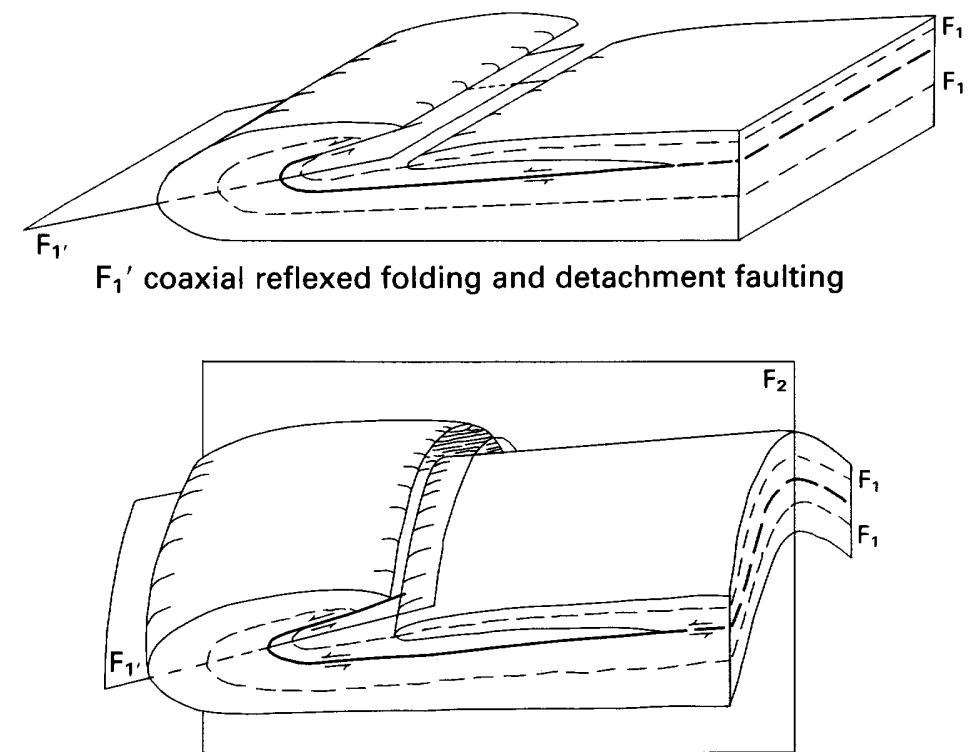

$F_{2}$ northeast-trending open folding

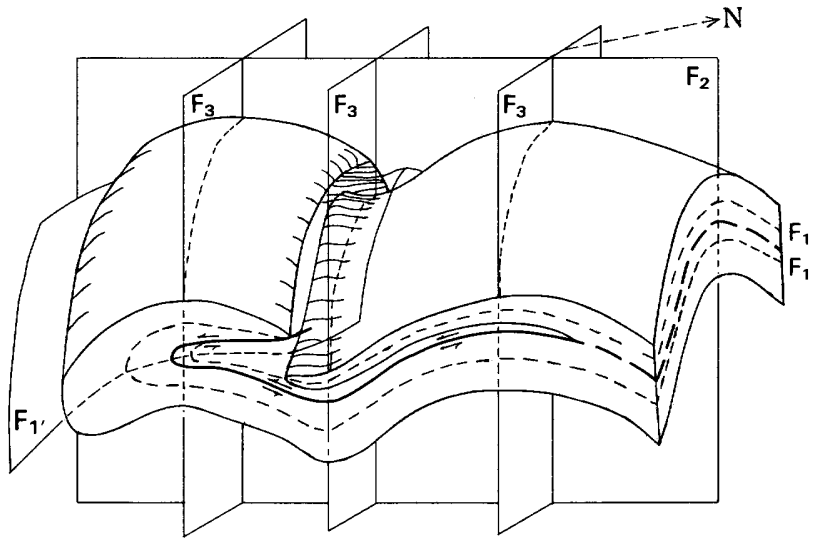

$F_{3}$ northwest-trending open folding

FIGURE 2.-Sequential structural development of the Hyde School domical gneiss body showing only alaskite part of the fold 
